ISSN 0258-7122 (Print), 2408-8293 (Online)

Bangladesh J. Agril. Res. 42(3): 531-538, September 2017

\title{
SEQUENTIAL APPLICATION OF BIO-PESTICIDE, BOTANICAL AND CHEMICAL INSECTICIDE TO MANAGE APHID AND POD BORER ATTACKING YARD LONG BEAN
}

\author{
M. R. AMIN ${ }^{1}$, A. A. TARIF ${ }^{2}$, M. M. RAHMAN ${ }^{3}$ \\ M. M. HOSSAIN ${ }^{4}$ AND F. GE
}

\begin{abstract}
Present study evaluated the effect of sequential application of a bio-pesticide (Bacillus thuringiensis subsp. Kurstaki) (Bt), a botanical (neem oil) and a chemical insecticide (cypermethrin 25EC) as well as cypermethrin 25EC alone in the management of aphid (Aphis craccivora) and pod borer (Maruca vitrata) attacking yard long bean (Vigna unguiculata sesquipedalis) in the field. In each treatment $B t$, neem oil and cypermethrin were applied in alternative sequence as well as cypermethrin alone at 07 days intervals. All the treatments reduced aphid population and flower infestation after 24,48 and $72 \mathrm{~h}$ of treatment compared to untreated control. Aphid population reduction by the treatments over control was ranged from 34.4 to $71.9 \%$, and the treatment with cypermethrin alone had the lowest abundance of aphid and flower infestation. The $B t$ followed by neem oil and cypermethrin significantly reduced the pod infestation by pod borer and increased yield (38.9-41.4\%) over control with BCR: 1.85-2.16. Use of cypermethrin alone was most effective and showed the lowest pod infestation and revealed the increased yield over control (47.7\%) with BCR 4.70. Considering the hazardous affect of cypermethrin alone, its application followed by bio-pesticide and botanical sequentially would be promising components for integrated pest management strategies against aphid and pod borer attacking yard long bean.
\end{abstract}

Keywords: Bacillus thuringiensis, cypermethrin, neem oil, yard long bean, sequentially.

\section{Introduction}

Yard long bean, Vigna unguiculata sesquipedalis is one of the most popular vegetables in Southeast Asia (AVRDC, 2001; Ali et al., 2002). It is a vigorous climbing annual vine crop and known as long poded cowpea or Chinese long bean or snake bean. The tender green pods of yard long bean are a good source of protein, iron, calcium, phosphorus, vitamin A, vitamin C and dietary fiber (Singh et al., 2001). Farmers in Bangladesh grow yard long bean throughout the year to meet high market demand, but the crop in subtropical conditions is highly prone

\footnotetext{
${ }^{1-3}$ Department of Entomology, Bangabandhu Sheikh Mujibur Rahman Agricultural University (BSMRAU), Gazipur 1706, Bangladesh, ${ }^{4}$ Department of Horticulture, BSMRAU, Gazipur 1706, Bangladesh, ${ }^{5}$ State Key Laboratory of Integrated Management of Pest Insects and Rodents, Institute of Zoology, Chinese Academy of Sciences, Beijing, China.
} 
to the attack of insect pests. The insects attack at flowering and post-flowering stages is a major factor to limit the production (Jackai et al., 1992). The aphid Aphis craccivora Koch (Hemiptera: Aphididae) and pod borer, Maruca vitrata Fabricius (Lepidoptera: Pyralidae) reduce the productivity significantly. The pod borer larvae damage flower buds, flowers, green pods and seeds of this crop thereby reduce $54.4 \%$ production (Singh and Jackai, 1988).

The aphid is a polyphagous insect which causes serious damage to bean plants from seedling to the pod bearing stage. They feed on phloem sap with their piercing sucking mouthparts, and their feeding injury causes leaf and fruit growth abnormalities, leaf yellowing and curling, reduction of leaf canopy area, and senescence of premature leaves (Beckendorf et al., 2008). Aphid infestations reduce branching and the infested plants become stunted, suffer from withering or shedding of flowers, and produce lower number of pods (Beckendorf et al., 2008). This insect also plays a role in the transmission of necrotic yellow, mosaic yellow and leaf roll viruses in bean plants (Smith and Boyko, 2007).

To reduce the crop loss, farmers indiscriminately use chemical pesticides. The synthetic chemicals destroy indigenous biodiversity, cause personal and environmental hazards and develop resistance in insects (Hoi, 2010). The lower mammalian toxicity and rapid degradation of botanical pesticides make them a suitable tool in integrated pest management programs (Amin et al., 2000; Roy et al., 2012; Roy et al., 2014). Some essential oils have insecticidal activities on Diptera larvae and adults (Chang et al., 2009). Bio-pesticides are one of the most effective tools available for managing vegetable pests. However, complete reliance on botanical or bio-pesticides alone seems to be less effective in reducing the economic damage caused by insects on vegetables. Hence, this study was conducted to validate an integrated pest management strategy by applying neem oil, Bacillus thuringiensis $(B t)$ and cypermethrin at an alternative sequence and cypermethrin alone for the management of aphid and pod borer attacking the yard long beans in the field with special emphasis on the yield and benefit cost ratio.

\section{Materials and Method}

\section{Experimental site and duration}

The study was conducted in the field laboratory of the Department of Entomology, Bangabandhu Sheikh Mujibur Rahman Agricultural University, Gazipur during January to May, 2016.

\section{Experimental design and cultivation of yard long bean}

Yard long bean seeds were collected from the Horticulture Research Center of Bangladesh Agricultural Research Institute (BARI) and cultivated in a randomized complete block design with a plot size of $4 \mathrm{~m} \times 4 \mathrm{~m}$. Seedlings were grown in a nursery to prevent damage from pests and diseases. Ten day, old 
seedlings were transplanted in the plots. The spaces between blocks and between plots were $0.5 \mathrm{~m}$ and $1.0 \mathrm{~m}$, respectively. Seedlings were transplanted on 16 January, 2016 in rows. Each plot contained 5 rows and each row had 5 pits separated by $60 \mathrm{~cm}$. At the stage of branching, the plants were supported by bamboo sticks to facilitate creeping. The manures and fertilizers were applied according to the recommended doses of BARI. Weeding, irrigation etc. were done whenever necessary. Pest incidences were monitored from one week after transplanting until last harvest.

\section{Experimental treatments}

Five treatments with an alternative sequential application of neem oil, $B$. thuringiensis (Bt) and cypermethrin 25EC (one after another) as well as cypermethrin alone were adopted. The $B t$ subsp. kurstaki were collected from the Ispahani Agro limited, Gazipur. Neem oil was bought from a pesticide shop in Dhaka. An untreated control was kept for scientific interpretation. Application of the treatments was started at the advent of the infestation of the pest and applied three times at weekly interval. The concentrations of $B t$, neem oil and cypermethrin were $5 \mathrm{ml} \mathrm{l}^{-1}$ water, $2.5 \mathrm{ml} \mathrm{l}^{-1}$ water and $0.5 \mathrm{ml} \mathrm{l}^{-1}$ water, respectively. The treatments with order of alternate sequence at weekly application are $B t \rightarrow$ cypermethrin $\rightarrow$ neem oil; cypermethrin $\rightarrow$ neem oil $\rightarrow B t$; neem oil $\rightarrow B t \rightarrow$ cypermethrin; cypermethrin $\rightarrow B t \rightarrow$ neem oil; cypermethrin alone (three times), and control.

\section{Data collection}

The numbers of aphid per inflorescence were counted at 24, 48, and $72 \mathrm{~h}$ after each treatment. The topmost inflorescence from the third plant of the third row was used for counting the aphid population. The total number of bloomed flowers and the number of infested flowers of the topmost inflorescence from the third plant of the third row were counted to calculate the flower infestation level.

Healthy and infested (bore holes with or without frass) pods were plucked and percent pod infestation was calculated at each harvest. The recorded pod infestation at each harvest was pooled for the entire season and the mean pod infestation was derived for each replication. Yield was recorded at every harvest and the yields were categorized as marketable and infested based on the absence or presence of pod borer infestation. The pod yield recorded during each observation was pooled for the entire season and the total pod yield was derived for each replication, which was then used for estimating the total yield in tons per hectare for each treatment.

Data analysis: Data were analyzed by general linear model (GLM) followed by analysis of variance (ANOVA) and then mean comparisons were done by Duncan's Multiple Range Test (DMRT) through SPSS (IBM SPSS statistics 21). 


\section{Results and Discussion}

\section{Result}

The effects of bio-pesticides and chemical insecticide on the population abundance of aphid attacking yard long bean inflorescence (number of aphid inflorescence $\left.{ }^{-1}\right)$ are presented in Table 1 . The treatments had significant effect $\left(\mathrm{F}_{5,144}=33.4, \mathrm{p}<0.001\right)$ on the abundance but the effects of hours after treatment $\left(\mathrm{F}_{2,144}=2.8, \mathrm{p}=0.06\right)$ and interaction between treatments and hours after treatment $\left(\mathrm{F}_{10,144}=0.28, \mathrm{p}=0.99\right)$ were insignificant. Aphid population abundance at 24,48 and 72 hours after treatment varied from $2.1 \pm 0.6$ to $6.4 \pm 1.4$, $1.8 \pm 0.7$ to $6.4 \pm 1.6$ and $1.6 \pm 0.5$ to $6.4 \pm 1.4$ inflorescence ${ }^{-1}$, respectively. The mean aphid population among the treatments varied from $1.8 \pm 0.6$ to $6.4 \pm 1.5$ inflorescence ${ }^{-1}$ and the results differed significantly $\left(\mathrm{F}_{5,156}=34.2, \mathrm{p}<0.001\right)$. The lowest and the highest populations were shown by cypermethrin $\rightarrow$ cypermethrin $\rightarrow$ cypermethrin; and control, respectively. Aphid population reduction over control varied from 34.4 to $71.9 \%$ and the treatment with cypermethrin alone showed the highest reduction.

Table 1. Effect of Bacillus thuringiensis (Bt), neem oil and cypermethrin applied sequentially at 7 days interval ( 3 times) on the population abundance of aphid attacking yard long bean inflorescence in the field

\begin{tabular}{|c|c|c|c|c|c|}
\hline \multirow{2}{*}{$\begin{array}{c}\text { Treatments with order of } \\
\text { alternative application } \\
\text { sequence }\end{array}$} & \multicolumn{3}{|c|}{ Number of aphid inflorescence ${ }^{-1}$} & \multirow{2}{*}{$\begin{array}{c}\text { Mean } \\
\text { population }\end{array}$} & \multirow{2}{*}{$\begin{array}{c}\% \\
\text { Population } \\
\text { reduction }\end{array}$} \\
\hline & 24 HAT & $48 \mathrm{HAT}$ & 72HAT & & \\
\hline $\begin{array}{l}B t \rightarrow \text { cypermethrin } \rightarrow \\
\text { neem oil }\end{array}$ & $3.9 \pm 1.7 \mathrm{bA}$ & $3.7 \pm 1.2 \mathrm{bcA}$ & $2.8 \pm 1.5 \mathrm{bcA}$ & $3.4 \pm 1.5 \mathrm{c}$ & 46.9 \\
\hline $\begin{array}{l}\text { Cypermethrin } \rightarrow \text { neem oil } \\
\rightarrow B t\end{array}$ & $3.7 \pm 1.2 \mathrm{bA}$ & $3.0 \pm 1.0 \mathrm{cA}$ & $3.0 \pm 1.5 \mathrm{bcA}$ & $3.2 \pm 1.3 \mathrm{c}$ & 50.0 \\
\hline $\begin{array}{l}\text { Neem oil } \rightarrow B t \rightarrow \\
\text { cypermethrin }\end{array}$ & $4.4 \pm 1.7 \mathrm{bA}$ & $4.4 \pm 1.3 \mathrm{bA}$ & $3.7 \pm 1.6 \mathrm{bA}$ & $4.2 \pm 1.5 b$ & 34.4 \\
\hline $\begin{array}{l}\text { Cypermethrin } \rightarrow B t \rightarrow \\
\text { neem oil }\end{array}$ & $3.7 \pm 1.4 \mathrm{bA}$ & $3.2 \pm 1.4 \mathrm{cA}$ & $3.0 \pm 1.9 \mathrm{bcA}$ & $3.3 \pm 1.6 \mathrm{c}$ & 48.4 \\
\hline $\begin{array}{l}\text { Cypermethrin alone (three } \\
\text { times) }\end{array}$ & $2.1 \pm 0.6 \mathrm{cA}$ & $1.8 \pm 0.7 \mathrm{dA}$ & $1.6 \pm 0.5 \mathrm{cA}$ & $1.8 \pm 0.6 \mathrm{~d}$ & 71.9 \\
\hline Control & $6.4 \pm 1.4 \mathrm{aA}$ & $6.4 \pm 1.6 \mathrm{aA}$ & $6.4 \pm 1.4 \mathrm{aA}$ & $6.4 \pm 1.5 \mathrm{a}$ & \\
\hline
\end{tabular}

Data expressed as mean \pm SD. Means followed by the same lowercase letter(s) in the same column or by the same uppercase letter(s) in the same row are not significantly different, as assed by DMRT ( $\mathrm{p} \leq 0.05)$.

Table 2 shows the yard long bean flower infestation levels caused by aphid in different treatments. The infestation levels ranged from $20.3 \pm 1.7$ to $52.6 \pm 10.3 \%$ and the results differed significantly $\left(\mathrm{F}_{5,48}=4.2, \mathrm{p}<0.01\right)$. All the treatments revealed significantly lower percentage of infestation compared to the untreated control. The treatment with cypermethrin alone applied three times resulted 
significantly lower level of infestation than its sequential application with $B t$ and neem oil.

There was significant difference $\left(\mathrm{F}_{5,48}=8.2, \mathrm{p}<0.001\right)$ in pod infestation levels of yard long beans caused by pod borer (Table 2). Pod infestation levels ranged from $14.8 \pm 1.3$ to $40.3 \pm 4.9 \%$, and the treatments had significantly lower percentage of infestation compared to control. The lowest infestation level was occurred when cypermethrin alone was applied three times.

Table 2. Effect of Bacillus thuringiensis (Bt), neem oil and cypermethrin applied sequentially at 7 days interval ( 3 times) on the flower and pod infestation of yard long bean by aphid and pod borer, respectively

\begin{tabular}{l|l|l}
\hline \multirow{2}{*}{$\begin{array}{c}\text { Treatments with order of } \\
\text { alternative application sequence }\end{array}$} & \multicolumn{2}{c}{ \% Infestation } \\
\cline { 2 - 3 } & $\begin{array}{c}\text { Flower infestation by } \\
\text { aphid }\end{array}$ & Pod infestation by pod borer \\
\hline$B t \rightarrow$ cypermethrin $\rightarrow$ neem oil & $35.1 \pm 2.7 \mathrm{bc}$ & $22.2 \pm 2.3 \mathrm{bc}$ \\
Cypermethrin $\rightarrow$ neem oil $\rightarrow B t$ & $25.9 \pm 3.9 \mathrm{bc}$ & $23.5 \pm 2.3 \mathrm{bc}$ \\
Neem oil $\rightarrow B t \rightarrow$ cypermethrin & $38.5 \pm 6.0 \mathrm{ab}$ & $25.0 \pm 2.6 \mathrm{~b}$ \\
Cypermethrin $\rightarrow B t \rightarrow$ neem oil & $30.7 \pm 4.6 \mathrm{bc}$ & $22.1 \pm 3.0 \mathrm{bc}$ \\
Cypermethrin alone (three times) & $20.3 \pm 1.7 \mathrm{c}$ & $14.8 \pm 1.3 \mathrm{c}$ \\
Control & $52.6 \pm 10.3 \mathrm{a}$ & $40.3 \pm 4.9 \mathrm{a}$ \\
\hline
\end{tabular}

Data expressed as mean \pm SD. Means followed by the same lowercase letter(s) in the same column or by the same uppercase letter(s) in the same row are not significantly different, as assed by DMRT ( $\mathrm{p} \leq 0.05)$.

Table 3. Yield of yard long bean obtained by the management of aphid and pod borer using the sequential application of Bacillus thuringiensis $(B t)$, neem oil and cypermethrin at 7 days interval ( 3 times)

\begin{tabular}{l|l|c|c|c}
\hline \multirow{2}{*}{$\begin{array}{c}\text { Treatments with order of } \\
\text { alternative application sequence }\end{array}$} & \multicolumn{3}{|c|}{ Yield (t/ha) } & \multirow{2}{*}{$\begin{array}{c}\text { Marketable } \\
\text { yield over } \\
\text { control }\end{array}$} \\
\cline { 2 - 5 } & Marketable & Infested & Gross & 41.4 \\
\hline$B t \rightarrow$ cypermethrin $\rightarrow$ neem oil & $9.9 \pm 0.7 \mathrm{ab}$ & $2.5 \pm 0.2 \mathrm{~b}$ & $12.4 \pm 0.8 \mathrm{a}$ & 40.2 \\
Cypermethrin $\rightarrow$ neem oil $\rightarrow B t$ & $9.7 \pm 0.4 \mathrm{ab}$ & $2.5 \pm 0.3 \mathrm{~b}$ & $12.3 \pm 0.5 \mathrm{a}$ & 40.8 \\
Neem oil $\rightarrow B t \rightarrow$ cypermethrin & $9.8 \pm 1.4 \mathrm{ab}$ & $2.6 \pm 0.3 \mathrm{ab}$ & $12.5 \pm 1.3 \mathrm{a}$ & 38.9 \\
Cypermethrin $\rightarrow B t \rightarrow$ neem oil & $9.5 \pm 0.8 \mathrm{~b}$ & $2.6 \pm 0.2 \mathrm{ab}$ & $12.1 \pm 0.9 \mathrm{a}$ & 47.7 \\
Cypermethrin alone (three times) & $11.1 \pm 0.4 \mathrm{a}$ & $1.9 \pm 0.3 \mathrm{c}$ & $13.0 \pm 0.5 \mathrm{a}$ & - \\
Control & $5.8 \pm 0.9 \mathrm{c}$ & $3.0 \pm 0.2 \mathrm{a}$ & $8.8 \pm 0.8 \mathrm{~b}$ & - \\
\hline
\end{tabular}

Data expressed as mean \pm SD. Means within a column followed by the same letter(s) are not significantly different as assessed by DMRT $(\mathrm{p} \leq 0.05)$.

There are significant differences in the marketable yield $\left(\mathrm{F}_{5,12}=14.4, \mathrm{p}<0.001\right)$, infested yield $\left(\mathrm{F}_{5,12}=6.7, \mathrm{p}<0.01\right)$ and gross yield $\left(\mathrm{F}_{5,12}=9.5, \mathrm{p}<0.01\right)$ of the yard long bean pods (Table 3 ). The marketable yield, infested yield and gross yield of the pods ranged from $9.5 \pm 0.8$ to $11.1 \pm 0.4,1.9 \pm 0.3$ to $3.0 \pm 0.2$ and $8.8 \pm 0.8$ to $13.0 \pm 0.5$ ton $\mathrm{ha}^{-1}$, respectively. All the treatments revealed significantly higher 
marketable yield and gross yield than untreated control. The infested yield was the highest $\left(3.0 \pm 0.2 \mathrm{t} \mathrm{ha}^{-1}\right)$ in the control treatment. The marketable yield and gross yield were the highest in the treatment with cypermethrin alone applied three times. Marketable yield over control varied from 38.9 to $47.7 \%$ and the treatment with cypermethrin alone showed the highest level.

The costs of the different treatments for aphid and pod borer management and the return obtained from the yard long bean yield are presented in Table 4. The cost was the lowest (TK. 18580/=) for the treatment with cypermethrin alone applied three times accordingly its gross return (TK. 222000/=), net return (TK. 203420/=), adjusted net return (TK. 87420/=) and BCR (4.70) were the highest.

Table 4. Benefit-cost ratio analysis of Bacillus thuringiensis (Bt), neem oil and cypermethrin applied sequentially at 7 days interval $(3$ times) for management of aphid and pod borer in yard long bean field

\begin{tabular}{l|c|c|c|c|c}
\hline $\begin{array}{c}\text { Treatments with order of } \\
\text { alternative application sequence }\end{array}$ & $\begin{array}{c}\text { Manage- } \\
\text { ment } \\
\text { Cost }(\text { Taka) }\end{array}$ & $\begin{array}{c}\text { Gross } \\
\text { return } \\
\text { (Taka) }\end{array}$ & $\begin{array}{c}\text { Net } \\
\text { return } \\
(\text { Taka) }\end{array}$ & $\begin{array}{c}\text { Adjusted } \\
\text { net return } \\
\text { (Taka) }\end{array}$ & BCR \\
\hline$B t \rightarrow$ cypermethrin $\rightarrow$ neem oil & $25930 /=$ & $198000 /=$ & $172070 /=$ & $56070 /=$ & 2.16 \\
Cypermethrin $\rightarrow$ neem oil $\rightarrow B t$ & $25930 /=$ & $194000 /=$ & $168070 /=$ & $52070 /=$ & 2.0 \\
Neem oil $\rightarrow B t \rightarrow$ cypermethrin & $25930 /=$ & $196000 /=$ & $170070 /=$ & $54070 /=$ & 2.08 \\
Cypermethrin $\rightarrow B t \rightarrow$ neem oil & $25930 /=$ & $190000 /=$ & $164070 /=$ & $48070 /=$ & 1.85 \\
Cypermethrin alone (three times) & $18580 /=$ & $222000 /=$ & $203420 /=$ & $87420 /=$ & 4.70 \\
Control & --- & $116000 /=$ & $116000 /=$ & - & \\
\hline
\end{tabular}

$1 \mathrm{Kg}$ price TK. 20 only.

\section{Discussion}

This study clearly indicated that the abundance of aphid on bean inflorescence varied among the treatments. The application of cypermethrin alone and sequential application of cypermethrin, $B t$ and neem oil significantly reduced aphid population as well as flower infestation, but cypermethrin applied alone was found to be the most effective in reducing aphid population and flower infestation. The present findings corroborate with Weaver et al. (1997) who reported that the bio-pesticides and oils were subjected to simple chemical fractionation and had great potential for insect control.

Yule and Srinivasan (2014) reported that B. thuringiensis followed by cypermethrin reduced $23-85 \%$ yard long bean pod damage by $M$. vitrata. In the present study, sequential application of cypermethrin, $B t$ and neem oil showed significantly lower level of pod damage compared to untreated control. However, treatment with sequential use of cypermethrin followed by $B t$ and neem oil was not found to be superior compared to three times application of cypermethrin alone.

Chemical pesticides or $B t$ or neem oil could stress the exposing insect pests and subsequent application of $B t$ and neem oil on stressed pests could lead to high 
mortality rates (Khalique and Ahmed, 2001). But in this study, Bt, neem oil and chemical were used, because using the same pesticide or $B t$ or neem oil repeatedly might lead to the development of resistance in insects (Ekesi, 1999). Many studies confirmed moderate to high effectiveness of $B$. thuringiensis against M. vitrata in field conditions (Sunitha et al., 2008; Sreekanth and Seshamahalakshmi, 2012). However, an earlier study by Yule and Srinivasan (2013) revealed that $B$. thuringiensis alone could not reduce yield losses, and neem is effective only at higher concentrations for lepidopteran pests.

In this study, highest yield was obtained from the plants that were treated with only cypermethrin followed by the treatments with $B t$ and neem oil, and cypermethrin applied sequentially one after another at 7 days interval for three times. Yule and Srinivasan (2014) reported that B. thuringiensis in combination with cypermethrin reduced pod damage by $M$. vitrata in yard long bean and substantially increased yield $22-190 \%$. The present study showed that $B t$, neem oil and cypermethrin applied sequentially reduced aphid populations from 34.4 to $50.0 \%$ over control. The treatment combination reduced flower infestation by aphid, and pod infestation by borer, and resulted higher yield (38.9 to $41.4 \%$ over control). Annan et al. (1995) observed reduced plant growth and yield in the cowpea, Vigna unguiculata due to the infestation of A. craccivora. The gross return, net return, adjusted net return, and benefit-cost ratio of the treatments varied with their management expenditure and yield.

This study revealed that an integrated strategy based on $B t$, neem oil and cypermethrin applied sequentially could effectively curtail yield losses caused by aphid and pod borer in yard long bean. The sequential application of chemical insecticide, Bt and neem oil reduces the amount of chemical pesticides significantly in the environment, which might avoid the development of resistance and loss in biodiversity. Because of the global focus on improving the safety of pesticides for human health and the environment, it is necessary to replace chemical insecticides by bio-pesticides.

\section{References}

Ali, M., U. Faroog and Y.Y. Shih. 2002. Vegetable research and development in the ASEAN region: a guideline for setting priorities. Asian Vegetable Res. Dev. Center. Pp. 20-64.

Amin, M. R., M. Shahjahan, H. F. Eltaj, T. M. T. Iqbal and M. A. Hossain. 2000. Use of akanda, biskatali and neem as botanical insecticides against lesser grain borer. Bangladesh J. Entomol.10: 1-13.

Annan, I. B., G. A. Schaefers and W. M. Tingey. 1995. Influence of duration of infestation by cowpea aphid (Aphididae) on growth and yield of resistant and susceptible cowpeas. Crop Prot. 14: 533-538.

AVRDC. 2001. AVRDC Annual report 2001. Shanhua, Tainan (Taiwan). Asian Vegetable Res. Dev. Center. p. 57. 
Beckendorf, E. A., M. A. Catangui and W. E. Riedell. 2008. Soybean aphid feeding injury and soybean yield, yield components, and seed composition. Agron. J. 100: 237-246.

Chang, L. C., I. K. Cho and Q. X. Li. 2009. Insecticidal activity of basil oil, transanethole, estragole and linalool to adult fruit flies of Ceratitis capitata, Bactrocera dorsalis and Bactrocera cucurbitae. J. Econ. Entomol. 102: 203-209.

Ekesi, S. 1999. Insecticide resistance in field populations of the legume pod borer, Maruca vitrata Fabricius in Nigeria. Intl. J. Pest Manage. 45:57-59.

Hoi, P. V. 2010. Governing pesticide use in vegetable production in Vietnam. Ph. D. Dissertation, Wageningen Univ., Netherlands. p. 181.

Jackai, L. E. N., E. E. Inang and P. Nwobi. 1992. The potential of controlling post flowering pests of cowpea, Vigna ungiculata (L.) Walp using neem, Azadirachata indica. Tropical Pest Manag. 38: 56-60.

Khalique, F. and K. Ahmed. 2001. Synergistic interaction between Bacillus thuringiensis (Berliner) and Lambda-cyhalothrin (pyrethroid) against chickpea pod borer, Helicoverpa armigera (Hubner). Pak. J. Biol. Sci. 4:1120-1123.

Roy, B., M. R. Amin, S. Jalal, Y. J. Kwon, S. J. Suh. 2014. Evaluation of common cocklebur Xanthium strumarium leaf extract as post-harvest grain protectant of black gram against pulse beetle Callosobruchus chinensis (Coleoptera: Bruchidae) and isolation of crude compound. Ent. Res. 44: 254-261.

Roy, B., S. Jalal, B. C. Sarker, M. R. Amin, Y. H. Jeon, I. J. Chun. 2012. Evaluation of insecticidal activities of common cocklebur fruit extract against pulse beetle Callosobruchus chinensis (Coleoptera: Bruchidae). Korean J. Appl. Entomol. 51: 325-329.

Singh, J., G. Kalloo and K. P. Singh. 2001. Vegetable crops: Nutritional security. Indian Inst. Vegetable Res., Varanasi. p. 56.

Singh, S. R. and L. E. N. Jackai. 1988. The legume pod borer Maruca testulalis (Geyer): past, present and future. Insect Sci. Appl. 9: 1-5.

Smith, C. and E. Boyko. 2007. The molecular bases of plant resistance and defense responses to aphid feeding: current status. Ent. Exp. Appl. 122: 1-16.

Sreekanth, M. and M. Seshamahalakshmi. 2012. Studies on relative toxicity of biopesticides to Helicoverpa armigera (Hubner) and Maruca vitrata (Geyer) on pigeonpea (Cajanus cajan L.). J. Biopest. 5:191-195.

Sunitha, V., K. V. Lakshmi and G. V. R. Rao. 2008. Laboratory evaluation of certain insecticides against pigeonpea pod borer, Maruca vitrata Geyer. J. Food Legumes. 21:137-139.

Weaver, D. K., L. J. Zettler, C. D. Wells, J. E. Baker, W. Bertsch and J. E. Throne. 1997. Toxicity of fractionated and degraded Mexican marigold floral extract to adult Sitophilus zeamais (Coleoptera: Curculionidae). J. Econ. Entomol. 90: 1678-1683.

Yule, S. and R. Srinivasan. 2013. Evaluation of bio-pesticides against legume pod borer, Maruca vitrata Fabricius (Lepidoptera: Pyralidae), in laboratory and field conditions in Thailand. J. Asia-Pacific Entomol. 16:357-360.

Yule, S. and R. Srinivasan. 2014. Combining bio-pesticides and chemical pesticides to manage legume pod borer (Maruca vitrata) on yard-long bean in Thailand. Intl. $J$. Pest Manag. 60: 67-72. 